\title{
Important Rights and the Private Attorney General Doctrine
}

The private attorney general doctrine ${ }^{1}$ gives courts the discretion to award attorneys' fees to a party who vindicates a right that (1) benefits a large number of people, (2) requires private enforcement, and (3) is of societal importance. Of the three criteria, this last requirement has been the most troublesome. ${ }^{2}$ Specifically, what is an "important" right? In order to decide which rights are important, courts have been inclined to engage in vague and subjective inquiries, leaving the contours of the private attorney general doctrine largely undefined. As a result, the application of the doctrine has been unpredictable.

In the paradigm private attorney general case, ${ }^{3}$ a party brings suit to enforce a right left unenforced by the ordinary enforcement mechanisms of the political process. By awarding attorneys' fees for the enforceinent of soine rights but not others, a court applying the doctrine is in effect reordering public policy priorities estabhshed by the political process through the creation of judicial incentives for the enforcement of such unenforced rights. A court's ordering of these priorities will by defintion be different froin the ordering established by the political process; if the orderings were the same, there would have been no need for private enforcement. ${ }^{4}$ Under this characterization of its actions, the court's task

1. The private attorney general doctrine provides for the enforcement of public rights through the use of private lawsuits, as opposed to through public lawsuits brought by the attorney general. The incentive for the private suit is the award of attorneys' fees following successful enforcement of the litigated right.

The doctrine is an exception to the general American rule, under which each party bears its own legal expenses, including attorneys' fees. Under the private attorney general doctrine, the prevailing party's attorneys' fees are borne by the opposing party. Under the English rule, the prevailing party regularly recovers attorneys' fees as part of its costs.

The doctrine is a part of both federal and California law. At the federal level, the doctrine received significant common law acceptance before being invalidated by Alyeska Pipeline Serv. Co. v. Wilderness Soc'y, 421 U.S. 240 (1975). See infra notes 18-23 and accompanying text. In California, the doctrine existed initially as state common law. Surviving the impact of the Alyeska decision, the doctrine has been statutorily codified. See Cal. Civ. Proc. Code $\S 1021.5$ (West 1985); infra notes 27-28 and accompanying text.

2. Serrano v. Priest, 20 Cal. 3d 25, 46, 569 P.2d 1303, 1314, 141 Cal. Rptr. 315, 326 (1977); Comment, Court Awarded Attorney's Fees and Equal Access to the Courts, 122 U. PA. L. REV. 636, 674 (1974).

3. This Comment focuses on the paradigm case where the defendant is a state agency and the plaintiff is the party seeking attorneys' fees. For a discussion of variations on the paradigm case, see McDernott \& Rothschild, The Supreme Court of California, 1976-1977, Foreword: The Private Attorney General Rule and Public Interest Litigation in California, 66 CAL1F. L. REv. 138, 155-60 (1978).

4. See infra note 61 and accompanying text. 
is to articulate standards for the review of the political process's ordering of public policy priorities.

The judiciary, in reviewing results of the political process, must reconcile the tension between its own view of the public good and its recognition that its insularity from public opinion makes it less competent than the political process to determine public policy priorities. In the area of equal protection analysis, the judiciary resolves this tension by subjecting the results of the political process to differing levels of scrutiny, depending upon the rights and the class of persons affected in a particular case. ${ }^{5}$ If the rights are fundamental, or if the class of persons is suspect, the judiciary has reason to question the political process's results. ${ }^{6}$ The more reason the judiciary has for such questioning, the higher the level of scrutiny applied. The higher the level of scrutiny, the higher the propensity of the judiciary to strike down the results.

This Comment proposes an alternative to the subjective inquiries currently found in private attorney general cases. It suggests that the same method with which the judiciary resolves judicial review tensions in the equal protection context may be applied in the private attorney general context. ${ }^{7}$ Consequently, it proposes a test under the private attorney general doctrine for whether the political process's ordering of enforcement priorities passes judicial review. If the right left unenforced by the political process has its source in general economic and social-welfare legislation, rational basis scrutiny is triggered. If the unenforced right has its source in statutes protecting women and illegitimate children, intermediate scrutiny is triggered. If the unenforced right has its source in statutes protecting fundamental rights, ${ }^{8}$ or suspect classes based on race or national origin, strict scrutiny is triggered.

Where the political process's nonenforcement result survives the applicable level of scrutiny, its ordering of enforcement priorities should be upheld. Where the result does not survive the applicable level of scrutiny, the ordering should be overridden. A court overrides the political process's ordering by allocating, where the political process has not, enforcement resources in the form of attorneys' fees.

5. See infra notes $66-67$ and accompanying text.

6. See infra note 67 .

7. However, since the private attorney general doctrine protects rights left unenforced by the political process, and nonenforcement of a right by itself does not generally give rise to an equal protection claim, an equal protection claim is not a prerequisite for a private attorney general award.

8. The terms "fundamental right" and "important right" are not synonymous. "Fundamental right" is a term of art defined by the large body of equal protection and due process case law. See J. NowAK, R. Rotunda \& J. Young, HANDBOoK ON CONSTITUTIONAL LAW 460. 61 (2d ed. 1983). In contrast, no consensus exists as to the definition of "important right". 


\section{BACKGROUND}

Under the common-fund doctrine, where the litigation efforts of one class member result in the creation or preservation of a fund to be distributed among all members of that class, the litigating class member is permitted to deduct attorneys' fees from the fund before the proceeds are distributed. The rationale for this common law rule is that beneficiaries of the common fund must bear their fair share of the costs of creating the fund.

Where the litigation efforts of one member of a class do not result in the creation of a common fund, but nevertheless confer a substantial benefit on the class, the substantial benefit doctrine allows a court to award attorneys' fees in some circumstances. For example, where the opposing party is in a position to spread the costs of the proponent's attorneys' fees over the benefiting class, such fees may be assessed. Typical cases include derivative suits where the defendant corporation is able to spread plaintiff's costs among the benefiting shareholders, and suits agamst the state, where the state is able to spread the costs among the benefiting taxpayers. ${ }^{9}$

The private attorney general doctrine is an outgrowth of the common-fund and substantial benefit doctrines. Where a plaintiff successfully sues to enforce some public right, he has benefited the public. Courts award such a plaintiff attorneys' fees, reasoning that where a large number of people benefit from the vindication of an important right, it is unfair for the plaintiff to bear the entire litigation cost, especially where the cost is wholly disproportionate to the plaintiff's individual gain. Since imitially the defendants in private attorney general suits tended to be state agencies, ${ }^{10}$ the courts undoubtedly felt that by placing the plaintiff's litigation costs on the defendant-state, those costs would be borne by those receiving the benefits, society in general. The doctrine was further supported by the policy of encouraging public interest litigation by shifting costs away froin interests which otherwise could not afford to be represented in the courts. ${ }^{11}$

Attorney fee award calculations under the private attorney general doctrine usually are based upon a "lodestar" figure. Courts deternine the lodestar figure by multiplying the number of attorney hours spent on a case by a reasonable hourly rate. This figure is then increased or decreased depending on a number of factors. These factors typically include:

9. See generally Serrano v. Priest, 20 Cal. 3d 25, 34-42, 569 P.2d 1303, 1306-12, $141 \mathrm{Cal}$. Rptr. 315, 318-24 (1977).

10. See supra note 3 .

11. See generally Comment, supra note 2 , at $666-70$. 
(1) the novelty and difficulty of the questions involved, and the skill displayed in presenting them; (2) the extent to which the nature of the litigation precluded other employment by the attorneys; (3) the contingent nature of the fee award, both from the point of view of eventual victory on the merits and the point of view of establishing eligibility for an award $\ldots .^{12}$

A party seeking an award of attorneys' fees under the private attorney general doctrine must meet three requirements. ${ }^{13}$ First, by successfully bringing the lawsuit, the party must have conferred a significant benefit on the general public or a large class of persons. The rationale for this requirement is that in theory the party is acting on behalf of the state attorney general, and thus is promoting a state interest, as opposed to litigating a purely private dispute. The meaning of "significant benefit" is distinct from that of "substantial benefit" as used in traditional substantial benefit theory. Under the private attorney general doctrine, sigmificant benefit means that "the benefits conferred on the public need be no more tangible than the knowledge that a public right has been vindicated, while the substantial benefit theory requires something more 'concrete." "14

Second, the party must show that there was a necessity for private enforcement. This requireinent "essentially tests whether the public interest advanced by the hitigation would have been represented without the plamtiff acting as a private attorney general."15 If not, this requirement recognizes that since the burden borne by the party bringing suit is often disproportionate to that party's individual stake in the matter, the award of attorneys' fees is necessary "to secure representation of interests that might otlierwise remain unrepresented."16

12. Serrano v. Priest, 20 Cal. $3 d$ at 49, 569 P.2d at 1316-17, 141 Cal. Rptr. at 328. Serrano arose out of litigation brought by two public interest law firms that successfully challenged the state's public school financing system as violating the California Constitution's equal protection provisions. In determining the appropriate attorney fee award, the court in Serrano also added, based on the factual aspects of the case, the following factors:

(4) the fact that an award against the state would ultimately fall upon the taxpayers; (5)

the fact that the attorneys in question received public and charitable funding for the purpose of bringing law suits of the charaeter here involved; [and] ( 6 ) the fact that the monies awarded would inure not to the individual benefit of the attorneys involved but the organizations by which they are employed....

Id. (footnote omitted).

13. Id. at 45, 569 P.2d at 1314, 141 Cal. Rptr. at 325.

14. McDermott \& Rothsehild, supra note 3, at 151 (footnote omitted). See also Woodland Hills Residents Ass'n v. City Council, 23 Cal. 3d 917, 939-40, 593 P.2d 200, 212, 154 Cal. Rptr. 503, 515 (1979) ("[T] he legislature contemplated that [in applying the private attorney general doctrine] a trial court would determine the significance of the benefits, as well as the size of the class receiving the benefits, from a realistic assessment, in light of all the pertinent circumstances, of the gains which have resulted in a particular case.").

15. McDermott \& Rothschild, supra note 3, at 149 (footnote omitted).

16. Id. 
Third, the party must show that the right vindicated is an important right. This Comment addresses this final requirement.

Even when lacking statutory authority, courts have awarded private attorney general fees, reasonimg that such awards, like common-fund and substantial benefit awards, were within the inherent "equitable powers of the court."17 However, in 1975 the Supreme Court held in Alyeska Pipeline Service Co. v. Wilderness Society ${ }^{18}$ that the private attorney general doctrine had no place in federal common law. ${ }^{19}$ The Alyeska majority relied on two independent grounds. First, as a general rule, the Court stated that judicially mandated shifting of attorneys' fees is contrary to statutory authority. ${ }^{20}$ Second, the Court defended its holding on the ground that courts are incapable of determining which rights are "important" for the purposes of the private attorney general doctrime. ${ }^{21}$ "[C]ourts are not free . . . to pick and choose among plaintiffs and the statutes under which they sue and to award fees in some cases but not in others, depending upon the courts' assessment of the importance of the public pohicies involved in the particular cases."22 To do so "would unake major inroads on a pohicy matter that Congress has reserved for itself."23

17. La Raza Unida v. Volpe, 57 F.R.D. 94,96 (N.D. Cal. 1972).

18. 421 U.S. 240 (1975).

19. Alyeska involved a challenge by a public interest group of the Department of the Interior's issuance of construction permits to the joint venture constructing the Trans-Alaska pipeline. It is generally understood that $A$ lyeska categorically rejected the private attorney general doctrine. See The Supreme Court, 1974 Term, 89 HARv. L. REv. 47, $170-71$ (1975). Nevertheless, it is plausible that Alyeska could be limited so as to proscribe private attorney general awards only in environmental suits.

If the narrower reading of Alyeska is adopted, this Comment's proposal may have application in federal courts as well as in California courts. In the federal realm, the breadth of the proposal reaches beyond the circumstances enumerated in the Civil Rights Attorneys' Fees Awards Act. See infra note 27. For example, the Act does not award fees where plaintiff successfully brings suit against a defendant who has not complied with an affirmative action statute. In such circumstances, this Comment's proposal would award fees. See infra note 70.

20. Alyeska, 421 U.S. at 260-62. The Court reasoned that the "general statutory rule," established in an 1853 court-costs statute and carried forward by successor provisions, limits counsel fees to nominal amounts in the absence of contrary statutory authority. Id. at 251-60. Moreover, the Court found that the existence of numerous specific statutory provisions for awarding attorneys' fees creates a scheme under which such awards are to be left for Congress to determine. Id. at 260 62.

As the dissenting opinion of Justice Marshall makes clear, the majority's statutory analysis is unconvincing. The majority opinion itself recognizes that an established line of cases permits the award of attorneys' fees in disregard of the "general statutory rule." Id. at 257-60. For example, such fees may be assessed under the bad faith and common-fund doctrines. Id. at 274-78 (Marshall, J., dissenting).

21. Id. at 263-68.

22. Id. at 269.

23. Id. For a detailed discussion of Alyeska, see The Supreme Court, 1974 Term, supra note 19 , at $170-82$.

As this Comment will argue, where the rights at issue are not environmental rights involving 
The reaction to the Alyeska decision was immediate. The California Supreme Court, in Serrano v. Priest, ${ }^{24}$ refused to follow the lead of the Alyeska Court and upheld the validity of the private attorney general doctrine in California. The California Supreme Court distinguished Alyeska, stating that the Alyeska Court's proscription of judicial interference with legislative enforcement priorities did not apply where the right being litigated was constitutional rather than statutory. ${ }^{25}$ The Serrano court, however, also explicitly stated that the applicability of the private attorney general doctrine did not depend on the constitutional-statutory distinction. The court left open the possibility that California courts would not follow post-Alyeska federal precedent and would continue to award fees for the enforceinent of statutory rights. ${ }^{26}$

The Cahfornia legislature reacted with equal dispatch, and removed all doubt as to whether the private attorney general doctrine would be apphicable in California to statutory rights. Within days after the Serrano decision was announced, the legislature enacted section 1021.5 of the Califorina Code of Civil Procedure, authorizing the award of attorneys' fees for private enforcement of any 'important right affecting the public interest." 27 The California Supreme Court interpreted this provision as establishing conclusively that the private attorney general doc-

complex policy tradeoffs but rather are fundamental rights and rights of suspect classes, the judicial incompetence theory asserted by the Court does not apply. The special role courts traditionally have played in safeguarding fundamental rights and the rights of suspect classes gives courts special competence to determine whether those rights are "important" in the context of the private attorney general doctrine.

24. 20 Cal. 3d 25, 569 P.2d 1303, 141 Cal. Rptr. 315 (1977); see supra note 12 and accompanying text.

25. Serrano, 20 Cal. 3d at 46, 569 P.2d at 1315, 141 Cal. Rptr. at 326.

26. Id. at $45-47,569$ P.2d at 1315,141 Cal. Rptr. at 327.

27. Cal. Civ. Proc. Code $\S 1021.5$ (West 1985).

Upon motion, a court may award attorney's fees to a successful party against one or more opposing parties in any action which has resulted in the enforcement of an important right affecting the public interest if: (a) a significant benefit, whether pecuniary or nonpecuniary, has been conferred on the general public or a large class of persons, (b) the necessity and financial burden of private enforcement are such as to make the award appropriate, and (c) such fees should not in the interest of justice be paid out of recovery, if any. With respect to actions involving public entities, this section applies to allowances against, but not in favor of, public entities, and no claim shall be required to be filed therefor.

Id.

After considerable debate, Congress also reacted to Alyeska, albeit in a more limited fashion, by passing the Civil Rights Attorney's Fees Awards Act, Pub. L. No. 94-559, 90 Stat. 2641 (codified as amended at 42 U.S.C. $\$ 1988$ (1982)). This statute now provides:

In any action or proceeding to enforce a provision of sections 1981, 1982, 1983, 1985, and 1986 of this title, title IX of Public Law 92-318, or title VI or the Civil Rights Act of 1964, the court, in its discretion, may allow the prevailing party, other than the United States, a reasonable attorney's fee as part of the costs.

42 U.S.C. \$1988 (1982). 
trine extended to statutory as well as constitutional rights. ${ }^{28}$

II

\section{Discussion}

\section{A. The Problem}

Despite California's acceptance of the private attorney general doctrine, certain aspects of the doctrine remain far from clear. The primary ambiguity results from the doctrine's requirement that the right enforced be an "important right." In Woodland Hills Residents Association v. City Council, ${ }^{29}$ the court notes that the doctrine "provides no concrete standard or test against which a court may determine whether the right vindicated in a particular case is sufficiently 'important' to justify a private attorney general award." 30 The problem is apparent: the deternination of importance is essentially a subjective one, perhaps inherently incapable of principled judicial resolution. Where a court's decision on whether to award attorneys' fees is dependent on subjective criteria, the outcome of the court's determination can vary with each judge's personal values. Inconsistent outcomes, in turn, undermine the judiciary's credibility. ${ }^{31}$

Moreover, even if it were possible for judges to reach a consensus as to what is "important," such a determination would require the judiciary to engage in a legislative function at which it is not particularly competent. The judiciary would be made to pick and choose among rights, a task which requires an implicit judgment as to which policies are important and which are not. ${ }^{32}$ As one commentator has noted:

It is by no means clear why the courts are the appropriate locus for such [policy] decisions. It is appropriate for the courts to use their equitable powers where necessary to make statutory protections effective, because the rights have been enacted by the legislature. But to establish a crite-

28. Woodland Hills Residents Ass'n v. City Council, 23 Cal. 3d 917, 930-31, 593 P.2d 200, 206, 154 Cal. Rptr. 503, 509 (1979).

29. 23 Cal. 3d 912, 593 P.2d 200, 154 Cal. Rptr. 503 (1979).

30. Id. at 935, 593 P.2d at 209, 154 Cal. Rptr. at 512. With the quoted statement as a preface, the court provided the guideline that "in determining the 'importance' of the particular 'vindicated" right, courts should generally realistically assess the significance of the right in terms of its relationship to the achievement of fundamental legislative goals." Id. at 936, 593 P.2d at 210, 154 Cal. Rptr. at 513. This guideline, however, provides only that the final judgment rendered (e.g. "the 'vindicated' right") be directly related to an important right (e.g. "fundamental legislative goals"). For example, the plaintiff in Bruno v. Bell, 91 Cal. App. 3d 776, 154 Cal. Rptr. 435 (1979), would not have been successful on the attorneys' fees issue, even if his complaint had contained the boilerplate provision that plaintiffs rights of equal protection and due process had been violated. See infra text accompanying note 78. The boilerplate causes of action are too indirectly related to the right vindicated, and hence do not satisfy the Woodland Hills guideline. While useful, the guideline still leaves undefined the term "fundamental legislative goals," which essentially is the same term as "important right."

31. McDermott \& Rothschild, supra note 3, at 153.

32. Alyeska Pipeline Serv. Co. v. Wilderness Soc'y, 421 U.S. 240, 269 (1975). 
rion that seeks to promote such enacted rights but not others seems a legislative function . . . . Where rights are created by the legislature the courts may imply the existence of remedies necessary to their effective protection. [The courts] stand on less sure footing when [the courts] themselves attempt to arrange the priorities for public policy enforcement. $^{33}$

The problem posed by the importance requirement, then, is twofold. First, the term "important right" is so elusive as to escape easy definition. Second, the implementation of any definition requires the judiciary to set public policy priorities, a task at which it is not conpetent.

\section{B. Solutions Proposed by Other Commentators}

\section{Constitutional Rights as Important Rights}

One commentator has advocated defining important rights as constitutional rights. ${ }^{34}$ Thus, attorneys' fees under the private attorney general doctrime would be awarded to plamtiffs vimdicating constitutional rights, but not to plaintiffs vindicating purely statutory rights.

Allowing fee awards only where constitutional rights have been vindicated clearly would be judicially manageable since a plaintiffs success on the merits would normally entitle him to a fee award. Moreover, unlike a trade-off between environmental protection and economic growth, the trade-off between constitutional rights and other social values is one in which the courts have an independent and legitimate concern. Protection of constitutional rights is not solely a legislative responsibility. Furthermore, it would appear to be desirable to encourage vindication of constitutional rights, even at the potential expense of other social values. ${ }^{35}$

The courts and the remaining coninientators, however, have rejected equating inuportant rights solely with constitutional rights. While the California Supreme Court distinguished its Serrano decision from the United States Suprenie Court's Alyeska decision on the grounds that $A l y$ eska did not involve constitutional rights, the California court nevertheless hinted that it was not liniting the applicability of the private attorney general doctrine to constitutional rights. ${ }^{36}$ The California legislature's enactment of section 1021.5 and the subsequent decision in Woodland Hills removed all doubt by establishing that the California concept of inportant rights also enconipasses statutory rights. ${ }^{37}$

Most commentators have supported the California Supreme Court's

\footnotetext{
33. Comment, supra note 2, at 671.

34. The Supreme Court, 1974 Term, supra note 19, at 180.

35. Id. at $180-81$ (footnotes omitted).

36. Serrano v. Priest, 20 Cal. 3d 25, 47, 569 P.2d 1303, 1315, 141 Cal. Rptr. 315, 327 (1977).

37. Woodland Hills Residents Ass'n v. City Council, 23 Cal. 3d 912, 930-31, 593 P.2d 200, 206, 154 Cal. Rptr. 503, 509 (1979).
} 
interpretation, arguing that a contrary decision would have led to absurd results. These commentators reason that the California constitution is but a compendium of statutes, raising to the constitutional level such rights as that of the Huntington Library to a tax exemption. ${ }^{38}$ They note that the private attorney general doctrine would be an anomolous creature indeed if the constitutional right of the Huntimgton Library to a tax exemption were held to be more important than the statutory right of a person to be free from private racial discrimination when buying a home. ${ }^{39}$ Similar arguments can be made with respect to rights enumerated in the federal constitution. For example, our intuitions of justice indicate, and the practices of the courts have confirmed, that certain constitutionally enumerated rights, such as the right to contract, stand in less need of judicial protection than statutorily enumerated civil rights. ${ }^{40}$

\section{All Statutory Rights as Important Rights}

Another proposed solution would construe the important-right requirement so as to encompass all statutory rights. Nearly all commentators have adopted this position in one form or another. McDermott and Rothschild argue that " $[t]$ he best solution . . . is to treat the vindication of all statutory policies as important enough to warrant fee awards, provided the other two criteria [of necessity of private enforcement and significant benefit] are met." ${ }^{\prime 1}$ Another commentator suggests that the importance criterion be construed liberally so as not to prove an obstacle to private attorney general awards. ${ }^{42} \mathrm{~A}$ third commentator proposes that the legal representation of interests that otherwise would remain unrepresented is by itself important enough to relieve plaintiff of the burden of proving the importance of the vindicated right. ${ }^{43}$

Defining important rights as all statutory rights in effect eliminates the importance requirement altogether. Several arguments have been advanced in favor of disregarding the importance requirement. First, this approach would eliminate the necessity that the judiciary engage in a legislative function. The judiciary would not be required to pick and choose among statutes, a task which requires an implicit judgment as to which policies are important and which are not. ${ }^{44}$

38. See, e.g., McDermott \& Rothschild, supra note 3, at 145 (citing Cal. Const. art 20, $§ 2$ (added 1974, renumbered 1976)).

39. Id. (citing Cal. Health \& SAfety Code $§ 35700$ (West Supp. 1977)). See also supra note 38 and accompanying text.

40. See, e.g., Ferguson v. Skrupa, 372 U.S. 726 (1963) (rejection of right to contract claim not a violation of equal protection clause).

41. McDermott \& Rothschild, supra note 3, at 145-46.

42. Comment, The Private Attorney General in California-An Evolution of the Species, 18 SAN DiEgo L. REv. 843, 851 (1981).

43. Comment, supra note 2, at 671.

44. See supra text accompanying notes 32-33. 
Second, this approach would produce reliable, consistent results. The commentators argue that the question "what is important?" is essentially a subjective one, incapable of any principled resolution. Where a court's decision to award attorneys' fees is dependent on such a subjective determination, the results will vary with each judge's personal values. Widely inconsistent outcomes are inevitable. It therefore is argued that eliminating this inherently subjective element is the only means of facilitating consistency among private attorney general fee awards. ${ }^{45}$

Third, some commentators contend that eliminating the importance requirement would encourage public interest litigation, as intended by the legislature. Public interest attorneys would be assured that their efforts would not go unrewarded due to a court's antipathy to the right being litigated. Hence, these attorneys would be more willing to take up those causes traditionally unrepresented in the legal system. ${ }^{46}$ One commentator has argued that the representation of traditionally unrepresented interests would vimdicate the right of all to equal access to the legal system-a sufficient basis to warrant requiring nothing further for an award of private attorney general fees. ${ }^{47}$

Furthermore, these commentators insist, retaining the importance requirement of the private attorney general doctrine actually deters public interest litigation. Where the rewards to the public interest attorney are subject to uncertainty, public interest litigation is discouraged. Before taking a case, the public interest attorney evaluates the risk of losing it, and of consequently not being awarded attorneys' fees. Such risk assessments, to which attorneys are well accustomed, make it more likely that meritorious cases (the ones with a higher probability of winning) will be brought instead of frivolous cases. However, when the prior results are inconsistent, as opposed to merely risky, there is a lack of adequate information regarding such probabilities. Uncertainty encourages conservative behavior (i.e. behavior which minimizes the loss due to wasted effort). ${ }^{48}$ Consequently, public interest attorneys are likely to decline such cases, and public interest litigation will suffer..$^{49}$

Stronger arguments, however, reject a definition of important right which encompasses all statutory rights. First, the California Supreme Court has explicitly stated its disagreement with such a reductive definition as follows:

[T]he legislature obviously intended that there be some selectivity, on a qualitative basis, in the award of attorneys' fees under the statute, for

\footnotetext{
45. McDermott \& Rothschild, supra note 3, at 153.

46. Id. at 153-54.

47. Comment, supra note 2, at 674-81.

48. See generally J. RAWLS, A THEORY OF JUSTICE 153 (1971).

49. Comment, supra note 42 , at 847 .
} 
section 1021.5 specifically alludes to litigation which vindicates "important" rights and does not encompass the enforcement of "any" or "all" statutory rights. Thus, . . . the statute directs the judiciary to ascertain the "strength" or "societal importance" of the right imvolved. 50

Second, a definition of important right which encompasses all statutory rights encourages enforcmg statutes to the letter. Where the enforcement of statutory rights is not encouraged through the award of attorneys' fees, the enforcement of such rights is generally left to public enforcement agencies. Leaving the power to enforce rights in the hands of a public enforcer, such as the state attorney general, gives the public enforcer the power of nullifying particular laws, or particular applications of law, simply by declining to prosecute violators. However, if attorneys' fees are awarded to encourage the enforcement of statutory rights, the nullification power of the public enforcer would be diminished. Where the public enforcer declines to prosecute, the private enforcer may still bring suit to enforce, especially where private enforcement yields an expected positive net return to the private enforcer. ${ }^{51}$

The effect of awardimg attorneys' fees for the enforcement of all statutes, then, would be to encourage the overenforcement of statutes. ${ }^{52}$ Such a result is contrary to legislative intent and would impose very heavy social costs.

[Statutes] will almost always be overinclusive; read literally, they will forbid some conduct that the legislature ... which forumulated the rule did not in fact want to forbid. The costs of precisely tailoring the rule to the conduct intended to be forbidden are prohibitive given the limitations of human foresight and the inherent ambiguities of human language. ${ }^{53}$

The threat of incurring such social costs can be reduced by leaving to the public enforcer the discretion to enforce statutes in accordance

50. Woodland Hills Residents Ass'n v. City Council, 23 Cal. 3d 917, 935, 593 P.2d 200, 209, 154 Cal. Rptr. 503, 512 (1979).

51. R. POSNER, ECONOMIC ANALysis OF LAw 470-78 (1977).

52. The problem of encouraging the overenforcement of statutes in general is distinct from the problem of overencouraging the enforcement of trivial statutes. McDermott and Rothschild have argued that actions to enforce trivial statutes will not be encouraged by defining important rights as all statutory rights, because such actions will not be awarded attorneys' fees. The enforcement of trivial statutes fails to satisfy the private attorney general doctrine's significant benefit and necessity of private enforcement requirements. McDermott \& Rothschild, supra note 3, at 154. However, the more central problem-encouraging overenforcement--cannot be similarly downplayed just because both trivial and nontrivial statutes are subject to overenforcement.

The requirements of significant-benefit and necessity of private enforcement do not alleviate the problem of overenforcement of nontrivial statutes. Forcing compliance with nontrivial statutes, even to the extent of overenforcement, may nevertheless produce significant benefits to a large class of the public. Further, forcing overly strict compliance is likely to require private litigation. Thus, both requirements would be satisfied. See also infra note 58 .

53. R. POSNER, supra note 51 , at 471 . 
with the statutes' spirit though not necessarily in accordance with their letter.

[D] iscretionary nonenforcement is a technique by which the costs of overinclusion can be reduced without a corresponding increase in underinclusion (loopholes). The police overlook minor infractions of the traffic code; building inspectors ignore violations of building code provisions that, if enforced, would prevent the construction of new buildings in urban areas; air traffic controllers permit the airline to violate excessively stringent safety regulations involving the spacing of aircraft landing and taking off from airports. ${ }^{54}$

For example, in Western Oil \& Gas Association v. Air Resources Board, ${ }^{55}$ the plaintiff oil companies brought suit against the Air Resources Board, claiming that California's air pollution standards as set by the Board imposed an unduly harsh economic burden on industry. The California Supreme Court recognized that strict enforcement of the air quality standards might have unacceptably high social costs, stating that "[t]he economic consequences of air quality control regulation, including the impact of such regnlation upon the jobs of employees in regulated industries, are indeed important and must be taken into account."56 However, the court upheld the air quality standards, reasoning that the appropriate method for averting the dire consequences suggested by the plaintiff was to permit discretionary enforcement of the statute. If local and regional authorities believe that a state air pollution standard poses an unduly harsh economic burden on industry, that standard need not be strictly enforced. ${ }^{57}$

Similarly, with respect to private enforcement, the threat of incurring adverse social consequences can be reduced by giving courts the discretion to award attorneys' fees in cases where judgment against the violator of a statute is consistent with the spirit of the statute, and the discretion not to award attorneys' fees in cases where the letter, but not the spirit, has been violated. Awarding attorneys' fees for the enforcement of all statutory rights, however, would defeat this method of reducing adverse social consequences. In Western Oil, for example, if private

54. Id. at 472 .

55. 37 Cal. 3d 502, 691 P.2d 606, 208 Cal. Rptr. 850 (1984).

56. Id. at 507, $691 \mathrm{P} .2 \mathrm{~d}$ at $608,208 \mathrm{Cal}$. Rptr. at 852 .

57. Id. at 524, 691 P.2d at 619, 208 Cal. Rptr. at 863.

Underlying the court's assumption that local and regional authorities would not continue to enforce state air pollution standards in a manner that would economically overburden industry is the rationale that if the economic burden were indeed unduly harsh, then the problem could bc rectified through the pressures of popular opinion on the local or regional executive. The courts, in contrast, are in theory unresponsive to such pressures. For example, candidates for executive office often campaign on how vigorously they will enforce the criminal law, environmental protection statutes, civil rights, etc. However, judges, even those who are elected, are not permitted to "make pledges or promises of conduct in office other than the faithful and impartial performance of the duties of the ofice." A.B.A. CodE of Judicial Conduct Canon 7B(1)(c). 
attorneys general had been encouraged through the award of attorneys' fees to enforce California's air quality standards, the ensuing strict enforcement of the standards would have increased the risk of the grave economic consequences upon industry which the court sought to avoid through discretionary enforcement. ${ }^{58}$

Third, the commentators' claim that the judiciary is incompetent to determine priorities of public policy overstates the case. Courts inust often make such determinations out of necessity. As Justice Holmes said,

I think that the judges themselves have failed adequately to recognize their duty of weighing consideration of social advantage. The duty is inevitable, and the result of the often proclaimed judicial aversion to deal with such considerations is simply to leave the very ground and foundation of judgments inarticulate and often unconscious . . . .59

The critical point is not that courts should not order public policy priorities, but rather that they should do so in a inanner that is not overreaching or arbitrary. For the purposes of the private attorney general doctrine, this point requires only that the judiciary define important right in a principled and restrained manner. Once judicial standards are established which permit a principled definition of inportant right, the coinmentators' reinaining arguments for the inclusion of all statutory rights as important rights fall to the wayside. Principled definitional standards of important right will facilitate consistent judicial opinions. In turn,

58. Presumably McDermott and Rothschild would concede that California's air pollution standards are not trivial statutes. The extra measure of enforcement resulting from strict enforcement of the statutes (the difference in degree between overenforcement and regular enforcement) may have significant benefits on the general public by insuring very clean air. Thus, overly strict enforcement in many cases will meet the significant-benefit requirement. Further, assuming the public enforcer is unwilling to overenforce the statutes, private litigation will be necessary to assure strict compliance. Thus, the requirement of necessity of private enforcement will be met.

Under McDermott and Rothschild's proposal since both requirements are satisfied, attorneys' fees should be awarded to private litigants who successfully sue to force overly strict compliance. See supra note 52 and accompanying text. Such overenforcement, however, is precisely the result this Comment argues should be avoided.

The difficulty with McDermott and Rothschild's proposal is its failure to take into account the costs associated with successful private enforcement. For example, in deciding whether to award fees to a plaintiff who successfully compelled a defendant's strict compliance with California's air pollution statutes, McDermott and Rothschild would examine the benefits conferred by the litigation-very clean air for California residents. However, their test would not take into account the costs of plaintiff's success, such as lost employment for oil industry workers.

McDermott and Rothschild's test is not saved by the suggestion that courts subtract the social costs from the social benefits of plaintiff's successful action, and then award attorneys' fees only if the remainder is one of significant social benefit. This suggestion would require courts to ascertain, for example, the social benefits of very clean air and the social costs of unemployment, and somehow gauge the relative value of each. Such a task is surely beyond the competence of the courts.

59. Holmes, The Path of the Law, 10 HARv. L. REv. 457, 467 (1897); see also B. Cardozo, The Nature of the Judicial Process 98-141 (1921). 
consistent judicial opinions will encourage necessary public interest litigation through the award of predictable private attorney general fees. ${ }^{60}$

\section{Proposed Solution}

\section{Recharacterization of the Problem}

The problem of defining important right, as discussed in Section $A$, presents difficulties that seem insurmountable. As argued in Section $B$, all of the currently proposed solutions are unsatisfactory. Without an articulated defimition of the importance requirement, courts have had to hobble along in their determinations of which rights are sufficiently important to inerit the award of attorneys' fees. This Comment proposes to put aside these troublesome subjective inquiries and look instead to more judicially cognizable factors.

The private attorney general doctrine awards attorneys' fees to parties for vindicating certain rights. The purpose of the award is to encourage the private enforcement of such rights where enforcement is needed due to the absence of public enforcement. In awarding private attorney general fees, courts are ordering public policy priorities by deciding which policies should receive resources for enforcement. In so doing, the courts are in effect overriding the resource-allocation priorities previously established by the political process. ${ }^{61}$

One effect of the private attorney general doctrine, then, is to permit judicial review of the political process's manner of distributing enforcement resources. Upon review, a court may override the political process's nonallocation of resources for the enforcement of certain rights by reallocating resources for the enforceinent of those rights. Therefore, the problem of determining which rights merit the award of attorneys' fees

60. In his dissenting opinion in Alyeska, Justice Marshall suggested a possible third approach: that the contours of the private attomey general doctrine, and thus presumably the contours of the importance requirement, be determined by looking to the "guidelines developed in closely analogous statutory and nonstatutory attorneys' fee cases." Alyeska Pipeline Serv. Co. v. Wilderness Soc'y, 421 U.S. 240, 274 (1974) (Marshall, J., dissenting). However, the difficulty with this approach is that other related attorneys' fee doctrines, such as common-fund and substantial benefit, do not require courts to examine the relative importance of the rights being litigated. Thus, it is doubtful that Marshall's closely analogous cases will provide sufficient guidance in defining "important right."

As one commentator stated, "Marshall's test does not specify any standards for determining which statutory claims are important enough to merit judicial encouragement. Indeed, Justice Marshall's language implies that the [importance requirement] could be satisfied by a successful claim enforcing any statutory provision." The Supreme Court, 1974 Term, supra note 19, at 178-79 (footnotes omitted). If this commentator is correct, Justice Marshall's approach is no differcnt from the "important rights as all statutory rights" approach rejected above. See supra text accompanying notes $41-60$.

61. There is a distinction here between the political process that results in the enactment of a statute, and the political process that results in its enforcement. It is the latter political process which stands to be overridden by the courts' allocation of attorneys' fees. 
can be recharacterized as determining the circumstances under which it would be proper for the judiciary to override the ordering of enforcement priorities reached by the political process.

\section{The Recharacterized Problem Analyzed}

An examination of the judiciary's review of the failure of the political process to allocate enforcement resources reveals the fundamental tensions inherent in a constitutional democracy. First, the notion that democratic law aspires to satisfy the majoritarian will is in tension with the notion of law as an expression of the general good. Second, the judiciary's recognition of its limited competence to determine priorities of public policy is in tension with its hesitancy to compromise the general good by deferring to the political will. Third, the democratic assumption that individuals are bound by the democratic processes in which they participate is in tension with the belief that the mdividual has certain fundamental rights upon which no legitinate political process may intrude. ${ }^{62}$

In response to the first tension, while conceding that the political process must be allowed primacy in determining the ends to be served, the judiciary requires the government's political branches, at a mimimum, to be reasonable. In response to the second tension, while recognizing that "[t]he problems of government are practical ones and may justify ... rough accomodations," ${ }^{\prime 3}$ the judiciary nevertheless will not tolerate approximations varying too arbitrarily from the general good. ${ }^{64}$ In response to the third tension, the judicary acknowledges that certain "political choices-those burdening fundamental rights or suggesting prejudice against racial or other ininorities-must be subjected to close analysis im order to preserve substantive values of equality and liberty." 65

In the area of equal protection analysis the judiciary has developed a "level of scrutmy" analysis for resolving the tensions inherent in judicial review. ${ }^{66}$ When engaging in this analysis, a court subjects the legislative or executive action to one of three levels of scrutiny, depending on the class of persons and the rights affected by the action. The three levels are rational basis scrutiny, intermediate scrutiny, and strict scrutiny. If a particular legislative or executive act does not survive the appropriate level of scrutiny, the act is held to be unconstitutional. If it does survive, it is deemed constitutional. ${ }^{67}$ The three tensions discussed above and, in

\footnotetext{
62. L. TRIBE, AMERICAN CONSTITUTIONAL LAW 991-1003 (1978).

63. Id. at 997 (quoting Metropolis Theater Co. v. City of Chicago, 228 U.S. 61,69 (1913)).

64. Id. at 997.

65. Id. at 1000 .

66. Id. at 991-94.

67. See generally J. NowAK, R. RotundA \& J. Young, supra note 8, at 585-99. A thorough
} 
turu, the three judicial responses to each, run parallel to these three levels of scrutiny. In response to each tension, the court applies a specific level of scrutiny.

study of the law of equal protection is beyond the scope of this Comment. However, a review of the concepts relevant to "level of scrutiny" analysis will be useful.

In examining legislative or executive acts, three considerations are relevant. The first consideration is the acts purpose. The purpose must not be arbitrary or invidious. The second consideration is the act's classification. An act's classification is "a quality or characteristic or trait or relation, or any combination of these, the possession of which, by an individual, determines his membership in or inclusion within [a particular] class." Tussman and tenBroek, The Equal Protection of the Laws, 37 CALIF. L. REv. 341, 344 (1949). The classification determines what level of scrutiny is triggered. The third consideration is the relationship between the purpose and the classification. The degree of a legislative or executive act's arbitrariness can be measured by the lack of correlation between the act's purpose and the act's classification. A completely nonarbitrary act will have a classification that perfectly promotes the purpose of the act. A completely arbitrary act will have a classification that is totally unrelated to the purpose of the act. Within these two extremes, an act may be underinclusive, overinclusive, or both underinclusive and overinclusive. An underinclusive act will have a classification that does not fully encompass the class of persons intended to be covered by the act's purpose. An overinclusivc act will have a classification that includes persons not intended to be covered by the act's purpose. An act both underinclusive and overinclusive will have a classification that both does not fully cover persons intended to be covered and includes persons not intended to be included. Id. at 347-53.

The first level of scrutiny, rational basis scrutiny, requires only that the purpose of the legislative or executive act not be invidious or arbitrary, and that the act's classification be reasonably related to the purpose. Rational basis scrutiny is applied to legislative or executive acts that have the general nature of economic or social-welfare legislation. While purporting to set limits, rational basis scrutiny in practice results in complete judicial deference to the legislature or executive. Thus, a legislative or executive act which is subject to rational basis scrutiny is for all practical purposes assured of being upheld as constitutional. See infra note 81.

The second level of scrutiny, intermediate scrutiny, requires that the purpose of the legislative or executive act be an important government interest and that the act's classification be significantly related to the purpose. Intermediate scrutiny has been applied to classifications based on gender and illegitimacy. See J. NowAK, R. RotUnDa \& J. Young, supra note 8, at 595; see also Lalli v. Lalli, 439 U.S. 259 (1978); Craig v. Boren, 429 U.S. 190 (1976). The rationale for this higher level of scrutiny is that gender and illegitimacy classifications historically have resulted from invidious discrimination. However, compared to strict scrutiny, intermediate scrutiny's presumption of invidious discrimination is more readily rebutted, since benign motives are more likely to underlie classifications triggering intermediate scrutiny.

The third level of scrutiny is strict scrntiny. Strict scrutiny requires that the legislative or executive act's purpose be a compelling state interest and that the act's classification be narrowly tailored to the purpose. Strict scrutiny is triggered in two situations: (1) where the act infringes on a fundamental right; and (2) where the act's classification is based on race or national origin. While strict scrutiny purports to be only a very close judicial examination of legislative or executive acts, for all practical purposes, an act subject to strict scrutiny is assured of being held unconstitutional. See L. TRIBE, supra note 62 , at 1000.

Level-of-scrutiny analysis occupies a middle ground between the complete abdication of the judiciary to the majoritarian process and the complete judicial usurpation of the legislative function. Tussman and tenBroek, supra, at 366 . On the one hand, the judiciary continues to exercise significant powers of judicial review over legislative or executive acts. On the other hand, under level-of-scrntiny analysis, the judiciary does not claim to determine the proper ends and means of legislative or executive action. Rather, level-of-scrutiny analysis claims merely to examine legislative or executive acts to ensure that the purpose is not invidious or arbitrary and that the classifieation is reasonably tailored to its purposes. Railway Express Agency v. New York, 336 U.S. 106, 112-13 (1949) (Jackson, J., concurring). 
The similarity between the tensions faced by a court during judicial review of legislative or executive acts and during review of the political process's enforcement priorities suggests that the analytical tools of judicial review in the equal protection context are applicable to an analysis under the private attorney general doctrine. In short, the courts could deal with the silmilar tensions in a similar manner, namely by applying the same level-of-scrutiny analysis to both.

Under the private attorney general doctrine, the level of scrutiny chosen by the courts will depend on the class of persons and the rights affected by the political process's failure to allocate enforcement resources. In determiming the appropriate level of scrutiny, the courts may look to equal protection precedents for guidance. ${ }^{68}$ For example, where the right sought to be enforced affects the economic interests of citizens generally, the political process's nonenforcement result will be subject to rational basis scrutiny. In effect, the results of the political process will not be overridden. The court will not allocate enforcement resources where the political process did not, and there will be no award of fees. Where the political process results in not enforcing a right which protects a suspect class, then the process will be subject to heightened scrutimy. In these cases, the political process's result of not allocating resources toward enforcmg rights protecting a suspect class will be sustained only if the justifications for the result are important or compelling, and significantly related or narrowly tailored to the class affected.

Admittedly, the analogy between judicial review under equal protection analysis and judicial review for the purpose of awardimg attorneys' fees is not perfect. In the equal protection context, the judiciary reviews statutes and regulations, statements of policy whicli may be subject to facial analysis. In the attorneys' fees context, however, a court likely will have no articulated standards from which to infer a classification, since the results of the political process are often determined by the discretionary acts or ormissions of imdividual actors witlin the political process. Under the equal protection clause, level-of-scrutiny analysis depends on the existence of articulated policies, so that the court may determine from the face of the statute or regulation what level of scrutiny is triggered. ${ }^{69}$ Arguably, the inapplicability of level-of-scrutiny analysis in the equal protection context implies the inapplicability of level of scrutiny analysis in the context of the private attorney general doctrine where classifications generally are absent.

68. See supra note 67.

69. In the absence of a facial classification, analysis under the equal protection clause would require a court to judge the constitutionality of the legislative or executive act by the extent of the act's disparate impact, by the directness of the causality between the disparate effects and the discretionary state acts, and by whether the class of persons and the rights affected have a history of being unequally burdened for invidious reasons. See L. TRIBE, supra note 62, at 1023-32. 
The private attorney general doctrine, however, does not require a party to prove an equal protection claim in order to be awarded attorneys' fees. Otherwise, the doctrine would be limited to the enforcement of only constitutional rights. ${ }^{70}$ Rather, the courts should interpret the private attorney general doctrine as providing for a less formalistic examination of the results of the political process.

Under equal protection analysis, where the challenged act is the result of an actor's discretion, there is said to be no classification, since the actor generally does not articulate the standards by which he acts. However, it is quite easy to infer a classification from the act itself, simply by hypothesizing the existence of an administrative regulation which dictates the act. For example, assume that the state attorney general brings a criminal suit against Defendant for jaywalking because Defendant looks like a hippie. Then, the classification which can be inferred is "hippie," just as if there were some administrative regulation stating that "criminal actions shall be brought against jaywalking hippies."

Further, in himited cases, a classification may be inferred where the political process reaches a result of inaction, such as not enforcing a statute. Given a finte set of unenforced statutes, a classification may be inferred by hypothesizing an administrative regulation which specifies which statutes will not be enforced. For example, assume California has but three statutes: (1) bakers shall not work more than sixty hours per week; (2) fifty percent of the contracts for state-funded municipal projects shall be distributed to businesses operated by women; (3) no person shall be demied employment on the basis of race. Further, assuine that the political process reaches a result where statute (1) is enforced but

70. The court in Woodland Hills explicitly rejected limiting private attorney general awards to the vindication of constitutional rights. See supra notes 28 \& 37 and accompanying text. This Comment's proposal in effect limits the private attorney general doctrine to the vindication of fundamental rights and rights protecting suspect classes. However, the scope of this proposal goes beyond constitutional rights and extends to statutory protection of suspect classes.

For example, suppose California has matching fund programs in which the state shares the cost with a city for certain city projects. As one condition of qualifying for the matching funds, an affirmative action statute mandates that a certain percentage of the project's contracts be awarded to businesses operated by women and members of minority groups (i.e. suspect classes). Plaintiff brings suit, alleging that the city is in violation of the affirmative action statute, and prevails. Noncompliance with an affirmative action statute, by itself, is unlikely to give rise to an equal protection cause of action, since noncompliance is generally by the discretionary acts or omissions of individual actors within the political process. Discretionary acts and acts of omission are not likely to be accompanied by articulated standards from which suspect classifications or improper purposes may be inferred. See supra text accompanying note 69 . Thus, if private attorney general fees were awarded only for the vindication of constitutional rights, the plaintiff will not be awarded attorneys' fees.

However, under this Comment's proposal, the appropriate focus is the class protected by the statutory right vindicated, not whether there has been an equal protection violation. Since the affirmative action statute protects suspect classes, this proposal would award plaintiff attorneys' fees, even though there had been no equal protection violation. 
statutes (2) and (3) are not. A classification may be inferred from the nonenforcement of statutes (2) and (3) by hypothesizing an administrative regulation which states, "Statutes (2) and (3) shall not be enforced." Subjecting the administrative regulation to facial analysis, the classification is that class of persons intended to be protected by the unenforced statute. In this case, the classifications inferable from the nonenforcement are "women" and "race."

The level-of-scrutiny analysis in the context of the private attorney general doctrine relies on inferring classifications from the inaction of the political process. This inference seens justified in the private attorney general context, given that the distinction between inaction and the affirmative decision not to act is difficult to draw. For example, assume the Board of Supervisors of the city of San Francisco seeks to enforce an ordinance regulating public laundries within the municipality, which presumably it legitimately may do. However, the Board as a matter of discretion does not enforce the ordinance against Caucasian-operated laundries. The Board's inaction-lack of enforcement against whites-is clearly unconstitutional, just as though there had been an affirmative decision to enforce the ordinance only against nonwhites. ${ }^{71}$ Thus, an administrative decision which fails to enforce a statute is equally subject to attack as a decision which affirmatively enforces a statute.

Despite the differences between the equal protection and private attorney general doctrines, the sinilarities of the concerns addressed are strong enough to warrant the use of level-of-scrutiny analysis in both contexts. First, level-of-scrutiny analysis is a judicially prudent method of restraining the will of the political branclies of government. Second, under each doctrine, the judiciary is acting to shield interests which are underrepresented in the political process from the capricious whims of the majority. In addition, in botll cases, this method of analysis provides a solution to an otlerwise insoluble problem in a manner which is politically practicable.

In summary, level-of-scrutiny analysis offers an acceptable interpretation of the private attorney general doctrine. First, it keeps the courts from inaking "major inroads on a policy matter that [the legislature] has reserved for itself."72 Concededly, level-of-scrutiny analysis in effect prefers policies protecting fundamental rights and suspect classes over other policies. Thus, a court engaging in this analysis is in effect ordering the priorities of public policy. The pertinent issue, however, is the appropriate demarcation between policy matters reserved for the legislature and those justiciable by the courts.

71. See Yick Wo v. Hopkins, 118 U.S. 356 (1886).

72. Alyeska Pipeline Serv. Co. v. Wilderness Soc'y, 421 U.S. at 269; see supra text accompanying notes $22-23,33, \& 44$. 
Second, securing greater protection for fundamental rights and the rights of suspect classes traditionally has been an accepted role of the courts. Increased judicial intervention in this area, at the expense of the political decisionmaking process, is justified on numerous grounds. For one, fundamental rights are rooted in the Constitution, and the Constitution provides certain restraints on pure majoritarian decisionmaking. For another, suspect classes cannot fairly be left at the mercy of the political process because, as the history of invidious discrimination shows, such classes are likely to be denied full participation in the political process. For these reasons, heightened judicial protection for fundamental rights and suspect classes has become firmly entrenched in our democratic tradition. ${ }^{73}$

Third, another advantage of applying level-of-scrutiny analysis in the private attorney general context is that it accords with the case law mandating that courts be selective about the statutes under which they award attorneys' fees. ${ }^{74}$ This selectivity avoids niany of the problems of overenforcement. ${ }^{75}$ Yet it does not eliminate all the problenıs of overenforcement. Simce attorneys' fees generally will be awarded for the enforcement of fundamental right and suspect class statutes, there is the danger that these statutes will be overenforced. Nevertheless, with respect to fundamental right and suspect-class statutes, the curtailment of the political process's power of discretionary nonenforcement seems justified.

Finally, level-of-scrutiny analysis can produce consistent judicial decisions regarding the rights that merit the award of attorneys' fees. ${ }^{76}$ There is a plethora of equal protection precedents to which the courts may look in implementing the important-right requirement. These equal protection precedents determine which rights are fundaniental, which classes are suspect, what levels of scrutiny are triggered by which suspect classes, and what reasons are sufficient to overcome a given level of scrutiny. The precedents will serve to guide courts deciding cases involving the private attorney general doctrine. This consistency in turn will encourage public interest hitigation by reducing the uncertainty in the award of private attorney general fees. ${ }^{77}$

\section{Application of the Proposed Analysis}

The following examples illustrate the level-of-scrutiny analysis proposed by this Coinment. The examples assume that the private attorney

73. See United States v. Carolene Prods. Co., 304 U.S. 144, 152-53 n.4 (1938).

74. See supra text accompanying note 50 .

75. See supra text accompanying notes 51-57.

76. See supra text accompanying note 45 .

77. See supra text accompanying notes 46-48. 
general doctrinal requirements of significant benefit and necessity of private enforcement have been established.

Example 1: A private plamtiff, with standing, brings suit challenging the validity of section 104.10 of the Cahfornia Streets and Highway Code on grounds that the section conflicts with the California Constitution. ${ }^{78}$ Section 104.10 requires that revenues received by the state from leased properties acquired for future highway development be distributed to the counties. The purpose of the section is to compensate the counties for the property taxes lost due to state acquisition of such properties. However, article 19 of the California Constitution requires that lease revenues from such properties be used for highway construction and maintenance. Plaintiff prevails on the merits and section 104.10 is struck down.

Under the proposed model, attorneys' fees should be awarded only if the political process's justifications for not enforcing the litigated right do not survive the level of scrutimy invoked by the class of persons or the right affected. Here, the class of persons affected is the citizenry of Cahfornia and the right affected is that of California citizens not to have state monies dispersed among the counties. The class of persons affected in this case is not a suspect class. The California citizenry cannot be characterized as a discrete and msular minority because, by definition, it is vested with the political powers of the state. The right of taxpayers to have monies retamed by the state, as opposed to dispersed to the counties, is not a fundamental right. Consequently, rational basis scrutiny is triggered. Any plausible reason which is neither invidious nor arbitrary provides a rational basis for the political process's result. Thus, the court should defer to the political process and not allocate state resources to the enforcement of the particular right invoked. Therefore, plaintiff should receive no attorneys' fees.

Example 2: Plaintiff files suit against defendant city for the city's nonenforcement of rape laws. Plaintiff alleges that she was raped, that slie notified the police of the identity of the alleged rapist, and that the police nevertheless refused to mvestigate as a matter of policy. ${ }^{79}$ If plaintiff prevails, sliould she be awarded attorneys' fees? An award of attorneys' fees depends on whether the political process's nonenforcement of plaintiff's civil rights overcomes the appropriate level of scrutiny.

Intermediate scrutiny applies to this case because gender is the inferable classification. Rape laws primarily serve to protect women by deterring potential rapists. The political process has reached a result where the city las failed to enforce the rape laws. Thus, the class of persons affected by this particular result of the political process is women in the

78. See Bruno v. Bell, 91 Cal. App. 3d 776, 154 Cal. Rptr. 435 (1979).

79. Graham v. City of Biggs, 96 Cal. App. 3d 250, 157 Cal. Rptr. 761 (1979). 
city. ${ }^{80}$

Assume the record establishes that the only justifications for the absence of public enforcement by the city are neglect, mistake, bureaucratic inertia, cost and manpower savings, and the like. Judged by equal protection precedents, these justifications are not sufficiently important and not significantly related to the gender classification so as to satisfy intermediate scrutiny. First, neglect, mistake, and bureaucratic inertia, as justifications for a political result, barely survive rational basis scrutiny. ${ }^{81}$ Since intermediate scrutiny requires a closer fit between the purpose and the classification than does rational basis scrutiny, such reasons would not survive. Second, mere administrative conveniences, such as cost and manpower savings, also do not satisfy intermediate scrutiny. " '[A]dministrative convenience' is not a shibboleth, the mere recitation of which dictates constitutionality.",82

Because this political process result does not survive intermediate scrutiny, the court should override it, and allocate enforcentent resources in the form of attorneys' fees to encourage the enforcement of the civil right of women to have rape laws enforced.

Example 3: The pohitical process's inaction might satisfy intermediate scrutimy if it is shown that an important state interest is advanced by not enforcing a gender-based right and that the state interest is significantly related to the gender classification. Suppose there exists a statute that provides "No person shall be denied access to an educational institution on the basis of sex." Plaintiff brings suit against the state for maintaining one high school exclusively for women and another exclusively for men. Plaintiff asserts that the school board has violated the statute.

80. The rationale for the higher level of scrutiny is that society's past practices create a presumption that the systematic nonenforcement of statutes designed to protect a particular suspect class, such as rape laws, is the effect of invidious discrimination.

In this particular case, plaintiff could sue for damages and for an injunction prohibiting the police from contiuuing to follow their policy of not conducting rape investigations. However, plaintiff would not be able to sue to have the rape laws enforced against the alleged rapist, since victims do not have standing to compel the state to prosecute criminal suits. Linda R.S. v. Richard D., 410 U.S. 614,619 (1973).

81. In United States R.R. Retirement Bd. v. Fritz, 449 U.S. 166 (1980), the plaintiff offered evidence that a statute rescheduling pension payments was passed for irrational reasons, and sought to have the statute struck down as unconstitutional. The majority held, in effect, that satisfaction of rational basis scrutiny was automatic. The dissent argued for a "rational basis plus" scrutiny where inquiry would be made into the motives for the legislative act. If the motives were found to be irrational, the statute should be held unconstitutional. Id. at 182-98. Thus, if mistake, neglect, and bureaucratic inertia may be classified as irrational motives, a political process result which was the effect of neglect, mistake, and bureacratic inertia would not survive "rational basis plus" scrutiny. A fortiori, it would appear that neglect, mistake and bureaucratic inertia would not survive intermediate scrutiuy.

82. Frontiero v. Richardson, 411 U.S. 677,690 (1973). 
Given the plain language of the statute, plaintiff presuinably would prevail.

On the issue of attorneys' fees, however, defendant might establish by looking to equal protection precedents that there were sufficiently inportant reasons for the political process's nonenforcernent, and that such reasons were siguificantly related to the gender classification. For instance, such gender-based segregation has been justified on the theory that "adolescents inay study inore effectively in single sex schools."83 Such justification is not sufficient for a court to refuse to enforce a statute, but may be a sufficient justification to allow individual actors within the political process to exercise their powers of discretionary nonenforcement. If such a reason exists, and the reason is significantly related to the gender classification, plaintiff should not recover attorneys' fees.

Example 4: Unemployed plaintiff brings suit against the Department of Employinent challenging its practice of inquiring whether a woinan is preguant before providing unemployinent coinpensation. Plaintiff prevails on the grounds that the department's inquiry violates a woinan's right of privacy. ${ }^{84}$ The right to privacy is a fundamental right, so the political process's result of not enforcing this right would trigger strict scrutiny. To survive strict scrutiny, the defendant must show that there is a coinpelling state interest justifying the inaction. Since such scrutiny is generally " 'strict' in theory and fatal in fact," 85 it is unlikely that any justification of the nonenforcement will be found to be coinpelling. Thus, a court should allocate resources for the enforcement of the right of privacy by awarding attorneys' fees to plaintiff.

\section{The Hard Case: Applying Level-of-Scrutiny Analysis to Environmental Litigation}

Environmental litigation has been a major source of private attorney general suits. In Woodland Hills Residents Association v. City Council, ${ }^{86}$ the California Supreme Court suggested that "the private attorney doctrine inay find proper application in litigation involving, for example, racial discrimination, the rights of inental patients, legislative reapportionment and . . . environinental protection."87 However, the Court did not decide whether environinental rights are inportant rights for the purposes of the private attorney general doctrine, since the defendant did not challenge the plaintiff on that ground.

83. See Vorchheimer v. School Dist., 532 F.2d 880, 888 (3d Cir. 1976), aff'd mem. by an equally divided Court, 430 U.S. 703 (1977).

84. Gunn v. Employment Dev. Dep't, 94 Cal. App. 3d 658, 156 Cal. Rptr. 584 (1979).

85. Gunther, The Supreme Court, 1971 Term-Foreword: In Search of Evolving Doctrine on a Changing Court: A Model for a Newer Equal Protection, 86 HARv. L. REV. 1, 8 (1972).

86. 23 Cal. 3d 917, 593 P.2d 200, 154 Cal. Rptr. 503 (1979).

87. Id. at 935-36, 593 P.2d at 209-10, 154 Cal. Rptr. at 512-13 (footnotes omitted). 
Not surprisingly, courts have sphit on whether the enforcement of environmental protection statutes constitutes the enforcement of an important right. For example, in Rich v. City of Benecia, ${ }^{88}$ the court awarded attorneys' fees to plaintiff after he successfully compelled defendant to prepare an environmental impact report. The court reasoned "environmental concerns im general and the statutory policy in favor of use of environinental inpact reports in particular involve preeininently important public rights." 89 It viewed favorably the trial court's finding that plaintiff's action " 'effectuates a strong State policy to require a careful scrutiny of potential results before permitting the execution of projects that may significantly affect the environment." "90

By contrast, the United States Supreme Court in Alyeska Pipeline Service Co. v. Wilderness Society ${ }^{91}$ denied the award of attorneys' fees to a plaintiff who, on the basis of a statute, had successfully enjoined the Secretary of the Interior froin issuing permits to defendant for the construction of the trans-Alaska oil pipeline. The Supreine Court was unmoved by plaintiff's appeal to the importance of the right embodied in the vindicated statute, stating: "If the [statute] involved in this case is a matter of gravest importance, it would appear that a wide range of statutes would arguably satisfy the criterion of public importance." 92

Under this Cominent's proposed analysis, the typical environmental suit should not qualify for private attorney general awards. This Comment has suggested that attorneys' fees should be awarded only in cases where the result of the political process does not survive the level of scrutiny applied by the court. The applicable level of scrutiny is determined by examining the rights or the class of persons affected by the political process's result. Environmental suits, such as those seeking to enjoin building development for failure to file an environmental impact report, do not affect fundanental rights as defined in the equal protection context. Further, the class of persons affected by the failure of the city or developer to file an environinental inpact report usually is not a suspect class. Rather, those affected are of the general citizenry of the city. Thus, the result of the political process need only survive rational basis scrutiny. Given that any noninvidious and nonarbitrary result satisfies rational basis scrutiny, a court should uphold the result reached by the political process and deny the allocation of state resources for the enforcement of the right at issue. Therefore, attorneys' fees should not be awarded.

88. 98 Cal. App. 3d 428, 159 Cal. Rptr. 473 (1979).

89. Id. at $435,159 \mathrm{Cal}$. Rptr. at 478.

90. Id. at $436,159 \mathrm{Cal}$. Rptr. at 478 (quoting the unpublished trial court opinion).

91. 421 U.S. 240 (1975).

92. Id. at 264 . 
Two arguments support the contrary position, that attorneys' fees should be awarded in these cases to encourage environmental hitigation. First, typically, with environmental issues "citizens in great numbers [will] frequently have interests in common that, while of enormous significance to the society as a whole, do not imvolve the fortunes of a single individual to the extent necessary to encourage their vindication by private recourse to the courts." 93 Without the award of private attorney general fees, environmental interest law firms will be underfunded and environmental interests will remain underrepresented in the legal system. Second, environmental suits are precisely the kind of litigation sought to be encouraged by the private attorney general doctrine, inasmuch as they address "preeminently important public rights."

In response, as the schema proposed by this Comment suggests, the stronger arguments support not awarding private attorney general fees in environmental litigation. First, the fact that many would benefit from the judicial enforcement of a right does not by itself justify encouraging private enforcement of the right through the award of private attorney general fees. If the benefit to be gained is the recovery of damages, such as in a consumer fraud suit, then a private suit can be encouraged by awarding attorneys' fees under the common-fund theory. If the benefits are more undefined, then the courts begin to intrude on the legislative function of determining the priorities of public policy. This intrusion is especially problematic since the argument in favor of awarding attorneys' fees in environmental suits is that the general public benefits from such suits. The claim of general public benefit suggests that the appropriate forum is political, not judicial. Otherwise, courts could justify promulgating public policy on grounds that such policy is the will of the general public. Such lawmaking runs counter to the essence of the democratic process-that the will of the public be determined at the polls and not by an elite superimposing what it thinks the general public wants. ${ }^{95}$

Second, it is not indisputable that environmental suits are the kind of public interest litigation sought to be encouraged by the private attorney general doctrine. What is in the public interest as seen by one group may be contrary to the public interest as seen by another. ${ }^{96}$ This problem is particularly acute with environmental concerns, since the advancement of environmental interests is often at the expense of the interests of the unemployed and the poor. For example, the city of Berkeley, Cali-

93. Save El Toro Ass'n v. Days, 98 Cal. App. 3d 544, 552, 159 Cal. Rptr. 577, 581 (1979).

94. Rich, 98 Cal. App. 3d at 435,159 Cal. Rptr. at 478.

95. In contrast to environmental rights, rights of women and minorities are not adequately protected by the political process because of prejudices limiting full political participation. See generally United States v. Carolene Prods. Co., 304 U.S. 144, 152-53 n.4 (1938).

96. McDermott \& Rothschild, supra note 3, at 153; Comment, supra note 2, at 674; Comment, supra note 42 , at 850 . 
fornia recently held hearings to determine whether the Berkeley marina should be zoned for the development of an industrial park. Environmental groups opposed the plan, arguing that the inarina should be preserved in its natural state. Black civic groups supported the plan, arguing that the developinent would alleviate the high uneinployinent in Berkeley's poorer neighborhoods. ${ }^{97}$

This tension can be illustrated if it is assumed that the city of Berkeley, as a coinpromise measure, zones the Berkeley inarina as a combined industrial/recreational park. In order to achieve this end, the city passes stringent and extensive environmental ordinances applicable to firms operating in the park. Suppose, however, that several years later, in the midst of a recession, the city is faced with a severe uneinployment problein. In response to pressures froin the political process, the city's executive turns a blind eye to building code violations within the park in order to encourage business expansion and increase einployment.

Plaintiff brings suit seeking the enforcement of the building code. On the face of the ordinance, a court would have little choice but to decide for plaintiff. However, it would be highly dubious for a court to encourage suits like plaintiff's by awarding attorneys' fees. If a court did so, it would be ordering public policy priorities in direct affront to the political process. It seeins questionable to characterize an environmental suit such as this as public interest litigation, given that the political process has reached a result where greater einployment opportunities are deemed more in the public interest than environinental protection.

This exanple illustrates that circumstances arise where there will be no common consensus as to whether or not a given environmental suit is in the public interest. Where the political process has reached a result of nonenforceinent, an elite and politically insular judiciary should be loath to impose its will upon it.

\section{CONCLUSION}

This Comment has attempted to define the inportant-right requirement of the private attorney general doctrine by recharacterizing the problem as one of determining the proper judicial deference due the political process's nonenforcement of a given right. It then has argued that the amount of judicial deference due the political process in the private attorney general doctrine context is analogous to that due the political process in the equal protection context.

In the context of the private attorney general doctrine, this Com-

97. Daily Californian, Jan. 29, 1985, at 1, col. 2; see also Western Oil \& Gas Ass'n v. Air Resources Bd., 37 Cal. 3d 502, 507, 691 P.2d 606, 608, 208 Cal. Rptr. 850, 852 (1984); supra text accompanying note 56 . 
ment defines important right such that heightened judicial protection will be available for members of suspect classes and for fundamental rights. The proposal's practical acceptability is to be found in our legal system's established tradition that fundamental rights and suspect classes merit greater judicial protection and intervention. Tradition carries with it the moral persuasiveness necessary to impose the judicial will on an otherwise reluctant political body. The alternatives discussed and rejected by this Comment lack this tradition and thus may run afoul of the rule that the judiciary must act within the bounds of what is politically practicable. On this rule, the public credit of the law depends. Without this rule, in the face of defiance by the political branches, the judiciary will reveal itself to be merely a loud but paper tiger. ${ }^{98}$

Carl Cheng*

98. For example, perhaps in response to judicial overreaching, in the 1980 and 1981 Budget Acts the California legislature explicitly refused to budget for the payment of attorneys' fees awarded against the state under Cal. CIV. Proc. Code. $\$ 1021.5$ (West 1985). See Serrano v. Priest, 131 Cal. App. 3d 188, 182 Cal. Rptr. 387 (1982). Suit was brought challenging the constitutionality of the legislative acts. The supreme court denied review, thereby avoiding a direct confrontation with the legislature. The court stated in dicta that the legislature's acts, if adjudicated, would be found unconstitutional on separation of powers grounds. See Mandel v. Myers, 29 Cal. 3d 531, 629 P.2d 935, 174 Cal. Rptr. 841 (1981) (confirming that the separation of powers doctrine does not prevent a court's ordering payment of attorneys' fees from funds appropriated for operating expenses). Nevertheless, the court's admonition rings hollow, given that private attorney general claimants against the state remain without recourse.

- B.A. 1982, Yale University; J.D. 1985, Boalt Hall School of Law, University of California, Berkeley. 